\title{
Marketing to the marginalised: tobacco industry targeting of the homeless and mentally ill
}

\author{
D E Apollonio, R E Malone
}

See end of article for

authors' affiliations

......................

Correspondence to:

Ruth E Malone, RN, PhD,

FAAN, Department of

Social and Behavioral

Sciences, School of

Nursing, University of

California, San Francisco,

3333 California Street,

Suite 455, UCSF Box

0612, San Francisco, CA

94143-0612; rmalone@

itsa.ucsf.edu

Received 16 March 2005

Accepted 1 July 2005
Objectives: To describe the tobacco industry's relationships with and influence on homeless and mentally ill smokers and organisations providing services to them.

Methods: Analysis of internal tobacco industry documents and journal articles.

Results: The tobacco industry has marketed cigarettes to the homeless and seriously mentally ill, part of its "downscale" market, and has developed relationships with homeless shelters and advocacy groups, gaining positive media coverage and political support.

Discussion: Tobacco control advocates and public health organisations should consider how to target programmes to homeless and seriously mentally ill individuals. Education of service providers about tobacco industry efforts to cultivate this market may help in reducing smoking in these populations.
$\mathrm{S}$ tudies document the tobacco industry's marketing of cigarettes to marginalised groups. To increase sales and defuse potential political opposition, tobacco firms have directed marketing, philanthropy, and outreach campaigns to African Americans, ${ }^{1}$ Asian Americans, ${ }^{2}$ Latinos, ${ }^{3}$ and gay men, ${ }^{4}$ and made appeals to different segments of society based on factors such as age and sex. ${ }^{56}$ However, searches revealed no previous research on tobacco industry marketing to the homeless and seriously mentally ill, populations marked by extremely high smoking rates and unique in their simultaneous economic, psychological, social, and physiological vulnerability. ${ }^{7-11}$

Despite their low incomes, the homeless have characteristics that make them desirable "downscale" customers, a population segment that the tobacco industry identified as critical to its sales at least as early as the 1970s. ${ }^{12}{ }^{13}$ While there is no consistent definition in the literature of what constitutes the population of mentally ill individuals, most studies find that smoking rates are high in this population as well as among the homeless. Research identifies between a quarter and a third of the homeless as mentally ill, ${ }^{14}{ }^{15}$ and rates of mental illness and disability are even higher among the chronically homeless. ${ }^{16}$

Approximately two thirds of the severely mentally ill experience or risk homelessness, ${ }^{16}$ and the mentally ill are estimated to buy nearly half the cigarettes sold in the USA. ${ }^{17}$ Mental illness and chemical dependency, both of which impair critical judgment, may make the homeless more susceptible to marketing efforts that suggest cigarettes help people "cope with stress". ${ }^{17}$ Overall, less than one quarter of the US population smokes and smoking rates have declined since the 1960s.$^{18}$ By comparison, although it is difficult to determine the level of smoking in the homeless population, studies suggest that between $70-99 \%$ of homeless adults smoke. ${ }^{7-10}$ Also, smoking rates for individuals with severe mental illness, who are over-represented among the homeless population, have not been declining as have rates in the general population. ${ }^{19}$

Unlike some other disadvantaged groups, the homeless and seriously mentally ill do not share a common culture or pride in their identity that might lead them to organise on their own behalf. In addition, these groups are marginalised $^{20-22}$ both socially and economically and their needs are rarely a focus of tobacco control efforts. ${ }^{23}$ Organisations providing services may have different goals than homeless individuals. ${ }^{16}$ For all these reasons, it is important to better understand the nature and extent of tobacco industry influence on tobacco use among the homeless and seriously mentally ill. This paper examines internal tobacco industry documents to analyse tobacco industry involvement with the homeless and seriously mentally ill population.

\section{DATA AND METHODS}

In conjunction with legal settlements between 46 state attorneys general and the major tobacco companies in the USA, over 40 million pages of internal tobacco industry documents have been made publicly available. These documents are web accessible at the Legacy Tobacco Documents Library $^{24}$ and Tobacco Documents Online, ${ }^{25}$ as well as major US tobacco companies. Documents used for this paper were retrieved between December 2003 and December 2004.

Using previously established techniques for systematically searching tobacco documents archives, ${ }^{26}$ we began with initial search terms such as "homeless", and "mental illness". Searches were expanded with a "snowball" strategy, using contextual information from initial searches to identify additional search terms and relevant documents, including names of individuals/organisations, date ranges, places, and reference (Bates) numbers. Approximately 2500 internal tobacco industry documents pertaining to the homeless, mentally ill, homeless organisations, and psychiatric institutions were identified and screened for relevance. After eliminating irrelevant material and duplicates, we drew on approximately 400 documents to prepare this paper, dated from 1977 to 2001 . We also reviewed relevant secondary data

Abbreviations: LCHV, Lovisiana Coalition for Homeless Veterans; NCHV, National Coalition for Homeless Veterans; OSHA, Occupational Safety and Health Administration; PM, Philip Morris; RJR, RJ Reynolds; VFW, Veterans of Foreign Wars 
sources including newspaper and journal articles, accessed via PubMed, Jstor, and internet searches using Google. Data were managed using EndNote software, and analysed to determine the tobacco industry's practices and goals in dealing with the homeless and seriously mentally ill, and with organisations providing services to these populations.

\section{Tobacco industry marketing to the homeless}

In 1977, an international tobacco industry trade group, including representatives of all major cigarette companies, noted in a document on the social acceptability of smoking that "cigarette smoking is becoming a downscale social activity". ${ }^{27}$ As the disease effects of smoking became better understood, more affluent and educated people were the most likely to quit. ${ }^{28}{ }^{29}$ Cigarette companies thus increasingly marketed toward lower income, less educated, and minority segments of the US population. ${ }^{12}$ A marketing study done for RJ Reynolds (RJR) noted in a downscale market profile that this demographic was "more impressionable to marketing/advertising... they're more susceptible. They're less formed intellectually... more malleable" [Ellipses in original $].{ }^{12}$

By the early 1990s the homeless had become one of the subpopulations specifically targeted by major cigarette companies, in addition to general marketing efforts directed toward downscale consumers. ${ }^{30}$ For example, RJR included direct targeting to the homeless as part of an urban marketing plan in the 1990s, focused on the advertising of "value" brands to "street people". ${ }^{30}$ In 1990, American Tobacco supplied cigarettes for the movie "Robocop 3", which showed homeless activists smoking Pall Malls and Lucky Strikes. ${ }^{31}$ In addition to advertising, tobacco companies gave away cigarette brand logo products to the homeless-for example, in 1994 Philip Morris (PM) apparently distributed 7000 "Merit" cigarette brand labelled blankets to New York homeless shelters and homeless individuals. ${ }^{32}$ By the late 1990s, the ties between homelessness and smoking had grown so overt that a major marketing periodical characterised the target market of Brown and Williamson's GPC brand as "Homeless Man"..33

Offering free samples is a well established strategy by which tobacco companies recruit new smokers, ${ }^{34-36}$ and cigarette samples were distributed to homeless shelters, mental hospitals, and homeless service organisations. In 1988 alone, Lorillard Tobacco Company spent over \$570 000 on cigarette donations, ${ }^{37}$ though not all of these were distributed to marginalised populations. Internal company documents show that in a single month in 1990, however, Lorillard distributed over 100 sample packs apiece to a homeless shelter, a soup kitchen, and a mental health association. ${ }^{38}$ Similar donations were logged regularly from 1983 to at least $1993 .{ }^{39-46}$

\section{Cultivation of organisations serving the homeless and mentally ill}

At the same time that tobacco companies targeted consumers, they cultivated relationships with service organisations, apparently as a means to gain positive media coverage and fight smoking restrictions. Homeless service organisations received charitable contributions from tobacco companies over several years, ${ }^{47-49}$ at times as part of larger brand promotions. ${ }^{50-52}$ A single contribution sometimes served both to develop sales for the product and to develop a relationship with the recipient organisation, such as when cigarettes were donated to homeless shelters at Christmas. ${ }^{53}$ Some psychiatric hospitals were also targeted by the "value" brands of major cigarette companies for sales promotions and giveaways throughout the 1980s and 1990s. ${ }^{54} 55$
Although the public health community is widely aware that cigarette use kills one in two long time smokers, ${ }^{18}$ homeless services workers may express only limited concern about smoking. ${ }^{56}$ When service providers consider smoking, they sometimes focus on the type of cigarettes smoked rather than on the hazards of smoking itself. A 1993 article in Cancer Nursing, for example, discussed the higher health risks faced by homeless smokers because they often smoke butts, or reroll used cigarettes, risking the spread of infectious diseases. However, the proposed solution to this problem was itself problematic: suggesting that public health workers find ways for homeless smokers to acquire "clean" cigarettes while encouraging them to quit. Although the authors were aware of this tension, they believed that promoting cessation alone would be ineffective. They suggested that

\section{"...telling a homeless person to quit smoking may not be as effective an intervention as providing a way to more easily obtain fresh, unadulterated, "clean" cigarettes while simultaneously offering smoking cessation classes... one must consider that smoking is a major coping mechanism used by the homeless to deal with the stress of their day-to-day existence. ${ }^{\prime 57}$}

Homeless people do face multiple stressors, but smoking and the associated tobacco addiction have themselves been shown to increase anxiety ${ }^{55}$ and to exacerbate existing mental health problems. ${ }^{23}$ In addition, research suggests that the majority of homeless and seriously mentally ill smokers are interested in quitting, ${ }^{70}{ }^{61}$ and some homeless individuals prefer non-smoking facilities. ${ }^{62}$ Moreover, recent evidence shows that smoking cessation interventions in these populations can be successful. ${ }^{23} 6063-71$

Many organisations providing services to the homeless and seriously mentally ill appear to have been relatively sanguine about their relationship to the tobacco industry. Several organisations, including teen shelters, ${ }^{72}$ received or requested grants from the tobacco industry, particularly PM. ${ }^{48}$ 73-76 $^{\text {In }}$ part, this may reflect the fact that tobacco companies have specifically targeted workers at homeless shelters in marketing efforts. A marketing study commissioned by PM in 1995, for example, stated that volunteers in homeless shelters were the kind of urban consumer it was trying to reach with a new menthol cigarette. ${ }^{77}$

In some cases, organisations that provide services to the homeless and seriously mentally ill have purchased cigarettes for clients. ${ }^{78} 79$ Other organisations have sought cigarette donations. ${ }^{80}{ }^{81}$ Although Lorillard was the only company for which we could locate detailed records of cigarette donations, we found documents dated as late as 1999 showing that a range of organisations solicited cigarettes or coupons. These included psychiatric institutions, homeless shelters, nursing homes, drug treatment facilities, thrift stores, and convalescent care centres. ${ }^{53767880-97130}$ For example, the executive director of a shelter serving women and children wrote to RJR in 1992:

\section{"... I am specifically asking if you might consider giving us cigarettes, factory rejects or irregulars would be fine for our clients. When clients come to our door they are usually depleted of all funds and resources. We do not believe this is the most appropriate time to give up smoking, it simply add [sic] to their stress. ${ }^{\prime \prime 96}$}

Similarly, a residential treatment services organisation requested cigarettes from Lorillard for a client population made up largely of homeless substance abusers and the seriously mentally ill, and received two cases, containing 800 
sample cigarettes, in response. ${ }^{92}$ The attitude of many service providers seeking tobacco industry assistance is illustrated by a 1995 letter from a mental hospital representative seeking donations of cigarettes, in which she characterised the provision of cigarettes as "caring" for patients:

"If you could, by some miracle, donate cigarettes or tobacco to the hospital to the patients [sic] it would be very much appreciated. As you know, it is very hard to stop smoking and for some here it is all they have. A majority of the patients here do not have family who are involved or care enough about them to bring cigarettes to them. ${ }^{178}$

In addition, local homeless organisations have accepted the presence of tobacco industry employees as volunteers on work projects-for example, in 1998, PM arranged for employees to paint two women's dormitories as a work project at a homeless shelter. ${ }^{50}$ Such activities position the tobacco industry as sympathetic and benevolent, drawing attention away from its primary aims of promoting smoking and selling cigarettes.

Two specific cases offer further detail regarding this relationship between service providers and the tobacco industry.

\section{Benson \& Hedges music festivals}

Beginning in 1988, PM made charitable contributions to homeless services organisations using a portion of ticket revenues from Benson \& Hedges arts and music festivals. ${ }^{98} 99$ In addition, PM made a two year grant of $\$ 100000$ to the National Coalition for the Homeless.99-101 Shortly after making these contributions, in 1992, PM requested that another recipient, the Coalition for the Homeless in New York, ask local legislators to stop trying to pass clean indoor air laws and instead focus on problems of homelessness. The Coalition for the Homeless refused and claimed that they would not accept future tobacco industry funding. ${ }^{102}$ After hearing about the incident, New York Times columnist Anna Quindlen wrote an opinion piece supporting the Coalition for the Homeless and suggesting that other charitable organisations follow their lead. ${ }^{102}$ This was the sole incident uncovered in our research where the tobacco industry received negative publicity for its relationship with homeless organisations.

The Benson \& Hedges music festivals, which featured jazz, $R \& B$, and blues, continued to seek out local homeless service organisations as recipients of charitable contributions in cities where music festivals were held at least through 1999. ${ }^{103} 104$ Although we found no discussions of negative publicity from the Coalition for the Homeless incident in PM's internal memos, all organisations chosen to receive contributions were pre-screened by public relations firms, and proposed to the company for funding if they met two criteria. ${ }^{104}{ }^{105}$ First, the organisations stated that they had no problem accepting tobacco industry money. Second, shelters agreed to hold a press conference with industry representatives to advertise the contribution. While the majority of shelters proposed as recipients of contributions served adult men, PM also considered family shelters. ${ }^{105}$

The Benson \& Hedges promotions served two purposes: they were a means to reach a target market for the brand, ${ }^{5}$ and they were a way for PM to position itself as a "socially responsible" company through philanthropy. ${ }^{68}$ In at least one case, PM held a Benson \& Hedges blues concert in a homeless shelter, and most concert attendees were reportedly homeless. ${ }^{106}$ Contemporaneous media coverage of the Benson $\&$ Hedges blues concerts, as well as the PM country music and jazz festivals sponsored by other brands, noted that proceeds from the concert would benefit local or national homeless organisations. ${ }^{107} \mathrm{PM}^{\prime}$ 's effort to gain direct political support from the Coalition for the Homeless was ultimately unsuccessful, but the company did succeed in gaining considerable positive media coverage of its contributions. ${ }^{106} 107$

\section{Homeless veterans groups}

Cigarettes were included as part of military rations to soldiers from the first world war until 1972, ${ }^{108}$ resulting in tobacco addiction among thousands of soldiers. Once returned from active duty, veterans constituted a substantial market for tobacco companies, which have maintained close relationships with veterans' groups for decades. For example, the industry has sought out veterans' organisations to rally in support of industry policy positions, in recent years specifically to fight clean indoor air laws. ${ }^{109}$

Veterans themselves often experience long term health consequences after their service, suffering high rates of homelessness and mental illness compared to the population as a whole. ${ }^{110}$ Veterans' organisations estimate that over 250000 veterans are homeless, constituting a third of the homeless population. ${ }^{111}$ The tobacco industry has made financial contributions to several organisations that provide services to homeless veterans or claim to advocate on their behalf, and then used these relationships to advance its political agenda. Tobacco industry documents suggest that of these organisations, the National Coalition for Homeless Veterans (NCHV) has been most active in advocating for tobacco industry political goals.

The NCHV, a group based in Washington DC made up of community based homeless veteran service providers, claims 250 members $^{112}$ and has appeared repeatedly on behalf of the industry's efforts to prevent new smoking restrictions. The organisation testified during US Occupational Safety and Health Administration (OSHA) hearings on the regulation of tobacco in the workplace, ${ }^{113}$ was recruited again to advocate against smoke-free bars in New York, and worked to maintain unrestricted smoking in other states after the passage of smoke-free bars legislation in California. ${ }^{114} 115$ NCHV's executive director argued in 1994 before OSHA that,

"[Prohibiting] on the job smoking... would force homeless veterans - and others like them - back on the streets. We simply cannot place a recovering, unemployed veteran in such a restrictive environment and expect success. ${ }^{\prime 116}$

RJR recruited the NCHV (and other veterans groups such as the American Legion, AMVETS and local Veterans of Foreign Wars (VFW) groups) in 1994 and 1995 to appear in lieu of cigarette companies themselves in the industry's advocacy against clean indoor air laws. ${ }^{117}$ NCHV was also listed in an internal company document as a "very active" ally on behalf of PM's policy goals in 1997. ${ }^{114}$ Other organisations such as Colorado's Veterans for the Homeless, though apparently less politically active, received rent and food contributions from Kraft, ${ }^{118}$ another subsidiary of PM's parent company, now called Altria. ${ }^{119} \mathrm{PM}$, however, made press releases regarding the same contributions under its own name. ${ }^{120}$

Despite making relatively small financial contributions, tobacco companies appear to have been successful in recruiting homeless veterans groups as allies and in attracting associated positive media coverage. For example, a 2000 media event created by RJR benefited the Louisiana Coalition for Homeless Veterans (LCHV). In exchange for Doral cigarette pack seals collected at its "Red, White and Blue Salute" at a local bar, RJR contributed $\$ 1000$ to help build a 
drop-in centre for disadvantaged and homeless veterans. ${ }^{121}$ At another location in North Carolina, the company donated $\$ 1000$ to Disabled American Veterans. ${ }^{121}$ According to a company public relations document, the events gained RJR extensive positive media coverage. In several cases, the RJR press release lauding its contribution was printed verbatim in local newspapers. ${ }^{121}$ RJR internal documents, however, revealed that the event was arranged to sell cigarettes to veterans, an important market because $42 \%$ of Doral customers have ties to the military. ${ }^{121}$ According to the firm hired by RJR, the Quixote Group, each event generated approximately 20 media stories, all positive, reaching over a million readers and listeners, and increased cigarette sales at event locations. ${ }^{121}$

\section{DISCUSSION}

Our study has limitations. Because the company documents available to us for review are limited to those requested during legal discovery processes, and because of the sheer volume and limited indexing of the document collections, we have no way to determine whether we have reviewed all documents relevant to tobacco industry interest in the homeless and seriously mentally ill populations. This limitation means that we are unable to determine, for example, how trends in industry interest in the homeless and seriously mentally ill populations may have changed over time. The evidence also does not allow us to determine industry motivation for some activities, such as the donation of "value" brands to shelters, which could have been done to enhance marketing to this downscale segment of the market, but could also represent cost or excess inventory considerations, concerns about preserving the "upscale" reputation of "premium" brands, or other factors.

However, despite these limitations, this research reveals several ways that the tobacco industry has marketed cigarettes to the homeless and seriously mentally ill, and shows how it has used service providers to try to further its political goals. No previous studies we could locate have documented this phenomenon, which is congruent with the industry's targeting of other marginalised groups. These findings have several important implications for public health.

First, tobacco control advocates need to challenge the apparently common assumptions among service providers that tobacco is a resource and that their clients are too "stressed" to consider quitting smoking. ${ }^{96} 116$ Some service providers presume that cigarettes calm the homeless and seriously mentally ill, ${ }^{122}{ }^{123}$ making the provision of services less difficult. In some cases, service providers have argued that smoking bans in environments populated by the mentally ill (including many homeless shelters) threaten clients' mental and physical health. ${ }^{24}$ Similarly, family groups that speak on behalf of severely mentally ill patients have also advocated against smoke-free environments. ${ }^{79}$ Thus, despite the high incidence of tobacco related diseases among the homeless and seriously mentally ill, ${ }^{8}{ }^{125-128}$ organisations created to serve these individuals' needs may be furthering their addiction through misplaced compassion.

In general, homeless service organisations have viewed the proximate problems of lack of employment, income, counselling, and long term housing as more relevant to their clients than harms caused by smoking. ${ }^{84} 116$ Service organisations rarely consider smoking related disease effects in the homeless and seriously mentally ill population. ${ }^{10}$ Casual attitudes about smoking by service providers can lead non-smokers to initiate smoking, creating long term consequences more serious than the issues for which these individuals sought help. ${ }^{56}$ This triage by providers regarding the problems of homeless and seriously mentally ill individuals has led some

\section{What this paper adds}

This paper documents tobacco industry efforts to recruit smokers in populations - the homeless and mentally ill-that have not been previously studied, and to form alliances with organisations that provide services to these populations. Given continued high smoking rates among the homeless and mentally ill and the associated health risks, it suggests interventions to recruit service providers in efforts to reduce smoking prevalence in these populations.

service organisations to request goods and services from the tobacco industry and to accommodate its media and policy demands ${ }^{75} 129$ without necessarily recognising that they may be further compromising their clients' health and helping sustain tobacco addiction.

Second, because homeless shelter employees who smoke may not view client smoking as a problem, ${ }^{78} 85$ tobacco control advocates need to consider ways to educate and partner with service providers. For example, Hamilton Family Center, an emergency family shelter in San Francisco, is working with Tobacco Free Kids to develop an education programme about the dangers of secondhand smoke (Schick S, January 2005, personal communication). Education should also focus on the costs to homeless clients when organisations accept tobacco industry support and thereby enhance marketing opportunities.

Organisations that fund tobacco control programmes should consider making these populations a primary focus, encouraging service providers to develop cessation programmes and policies against tobacco distribution and tobacco industry funding. Programmes attempting to help these populations should also strive to find ways for service providers to benefit by choosing not to accept tobacco industry support.

The ethical implications of marketing an addictive and deadly product to a population characterised by high rates of mental illness, substance abuse, and economic disadvantage are even more troubling than those that are normally raised about cigarette marketing. The tobacco industry claims that it does not market to children because they are not capable of making adult judgments about smoking, ${ }^{123}{ }^{131}$ yet it markets to adults with mental illness whose judgment may be impaired. Targeting an addictive product to the economically disadvantaged means that individuals may buy cigarettes at the expense of food and shelter. ${ }^{132} 133$

The industry's efforts to develop connections with other marginalised groups have drawn criticism from public health advocates within the relevant communities. ${ }^{1-4}$ In some cases, marketing plans have been forestalled by vigorous advocacy, such as the aborted "Uptown" brand that RJR attempted to introduce for African Americans, which became a public relations disaster for the company. ${ }^{134}{ }^{135}$ Targeting of homeless people, however, has drawn very little defensive response.

This research suggests the complexity of intervening in smoking behaviour in marginalised populations suffering from multiple forms of disadvantage. Tobacco control advocates, public health workers, and funding organisations should consider whether and how their efforts affect homeless and seriously mentally ill individuals and those who provide services for them. Education of service providers about the tobacco industry's efforts to exploit the homeless and seriously mentally ill, and their organisations, could help address the harms from smoking suffered by these populations. 


\section{Authors' affiliations}

D E Apollonio, R E Malone, University of California, San Francisco, USA

Funding: American Legacy Foundation (Apollonio), National Cancer Institute CA90789 and CA109153 (Malone)

Competing interests: none declared

\section{REFERENCES}

1 Yerger VB, Malone RE. African American leadership groups: smoking with the enemy. Tobacco Control 2002;11:336-45.

2 Lew R, Tanjarsiri SP. Slowing the epidemic of tobacco use among Asian Americans and Pacific Islanders. Am J Public Health 2003;93:764-8.

3 Aguinaga Bialous S. Tobacco industry targeting of Latinos in the United States. Presented at: California Department of Health Services Priority Populations Conference; 13-15 October 2003; Marina Del Ray, California).

4 Smith EA, Malone RE. The Outing of Philip Morris: Advertising Tobacco to Gay Men. Am J Public Health 2003;93:988-93.

5 Philip Morris. Benson and Hedges 1989 Marketing Plan. 21 Sep 1988. Philip Morris. Bates No. 2040735799/5974. http:// legacy.library.ucsf.edu/tid/sjv35e00 (Accessed 20 Jan 2004).

6 Marketing Perceptions. Marlboro Promotion Concepts Focus Groups Summary. Feb 1993. Philip Morris. Bates No. 2040177452/7485. http:// legacy.library.ucsf.edu/tid/cyh92e00 (Accessed 20 Jan 2004).

7 Connor SE, Cook RL, Herbert MI, et al. Smoking cessation in a homeless population: there is a will, but is there a way? J Gen Intern Med 2002;17:369-72.

8 Snyder LD, Eisner MD. Obstructive lung disease among the urban homeless. Chest 2004; 125:1719-25.

9 Szerlip MI, Szerlip HM. Identification of cardiovascular risk factors in homeless adults. Am J Med Sci 2002;324:243-6.

10 Farrell $M$, Howes $S$, Taylor $C$, et al. Substance misuse and psychiatric comorbidity: an overview of the OPCS national psychiatric morbidity study. Addict Behav 1998;23:909-18.

11 Lee T, Hanlon J, Ben-David J, et al. Risk factors for cardiovascular disease in homeless adults. Circulation 2005:111:2629-35.

12 RJ Reynolds. Our Target Is (More) Downscale. 20 Sep 1989. RJ Reynolds. Bates No. 515603998/4000. http://legacy.library.ucsf.edu/tid/pbs92d00 (Accessed 22 Jul 2004).

13 Brooks H. Downscale Publications. 14 Feb 1977. Brown and Williamson. Bates No. 670065148/5150. http://legacy.library.ucsf.edu/tid/qcy79e00 (Accessed 22 Jul 2004)

14 Koegel P. The causes of homelessness. In: Homelessness in America. Washington: Oryx Press, 1996.

15 Lehman AE, Cordray DS. Prevalence of alcohol, drug, and mental disorders among the homeless: one more time. Contemporary Drug Problems 1993;20:355-83.

16 Substance Abuse and Mental Health Services Administration. Blueprint for change: ending chronic homelessness for persons with serious mental illness and/or co-occurring substance use disorders. Rockville, Maryland: Department of Health and Human Services, 2003, (DHHS Publication No. SMA-04-3870).

17 Lasser K, Wesley BJ, Woolhandler S, et al. Smoking and mental illness: a population-based prevalence study. JAMA 2000;284:2606-10.

18 Schroeder SA. Tobacco control in the wake of the 1998 Master Settlement Agreement. N Engl J Med 2004;350:293-301.

19 Lamberg L. Patients need more help to quit smoking. JAMA 2004:292:1286-90

20 Hall J. Marginalization and symbolic violence in a world of differences. Nursing Philosophy 2004;5:41-53.

21 Hall J. Marginalization revisited: critical, postmodern, and liberation perspectives. Advances in Nursing Science 1999;22:88-102.

22 Hall J, Stevens P, Meleis A. Marginalization: a guiding concept for valuing diversity in nursing knowledge development. Advances in Nursing Science 1994;16:23-41.

23 Williams $J M$, Ziedonis D. Addressing tobacco among individuals with a mental illness or an addiction. Addict Behav 2004;29:1067-83.

24 Legacy Tobacco Documents Library. http://legacy.library.ucsf.edu/ index.html (Accessed $15 \mathrm{Jul}$ 2003).

25 Tobacco documents Online. http://tobaccodocuments.org/ (Accessed 15 Jul 2003).

26 Malone RE, Balbach, eds. Tobacco industry documents: treasure trove or quagmire? Tobacco Control 2000;9:334-8

27 Philip Morris. First Report by Working Party on Social Acceptability of Smoking to International Committee on Smoking Issues. 14 Oct 1977. Philip Morris. Bates No. 1000221521/1558. http://legacy.library.ucsf.edu/tid/ sve84e00 (Accessed 13 Jul 2004).

28 de Walque D. Education, Information, and Smoking Decisions: Evidence from Smoking Histories, 1940-2000. 7 Jul 2004. [Working Paper]. http:// ideas.repec.org $/ \mathrm{p} / \mathrm{wbk} / \mathrm{wbrwps} / 3362 . \mathrm{html}$ (Accessed 13 Jan 2005).

29 Garvey AJ, Kinnunen T, Quiles ZN, et al. Smoking cessation patterns in adult males followed for 35 years. 2002. [Working Poster]. hitp:// www.hsdm. harvard.edu/pdf-files/Dr._Garvey.pdf (Accessed 13 Jan 2005)

30 RJ Reynolds. Project SCUM. 12 Dec 1995. RJ Reynolds. Bates No. 518021121/1129. http://legacy.library.ucsf.edu/tid/mum76d00 (Accessed 20 Jan 2004).

31 UPP Entertainment Marketing. Feature Memorandum. 1990. American Tobacco Company. Bates No. 10004026. http://tobaccodocuments.org/ atc/71006209.html (Accessed 28 Oct 2004)
32 Moore E. Re:Homeless Hunger Initiative. 6 Jan 1994. Philip Morris. Bates No. 2041965266B/5267. http://legacy.library.ucsf.edu/tid//he52e00 (Accessed 20 Jan 2004).

33 Urbanski A. PROMO Magazine. Joe Camel Meet George Generic; Brown \& Williamson Is Convinced It Can Pump Image Oriented Brand Equity into a Black and White Package Whose User Profile in New York City at Least Is Not the Marlboro Man but the Homeless Man. Nov 1998. Brown and Williamson. Bates No. 183020120. http://legacy.library.ucsf.edu/tid/ klul 1c00 (Accessed 22 Jul 2004).

34 RJ Reynolds. Marketing Research Report. Corporate Sampling Study. 1979. RJ Reynolds. Bates No. 501755342-501755373. http:// tobaccodocuments. org/rir/501755342-5373.html (Accessed 20 Dec 2004).

35 Katz S, Lavack A. Tobacco related bar promotions: insights from tobacco industry documents. Tobacco Control 2002;11(suppl I):i92-101.

36 Donnelly Marketing. Introducing Brown \& Williamson Corporation Kool Lights \& Ultras. 1982. R.J. Reynolds. Bates No. 502632023-502632070. http://tobaccodocuments.org/landman/502632023-2070.html (Accessed 20 Dec 2004).

37 Lorillard. Lorillard, Inc. And Subsidiaries Consolidated Condensed Balanced Sheet. 31 Dec 1988. Tobacco Documents Online. Bates No. 93483600/ 93484046. http://tobaccodocuments.org/lor/93483772-3777.html (Accessed 28 Oct 2004).

38 Lorillard. Sample 10 Log 1990 to 1991. 1991. Lorillard. Bates No. 87810958. http://legacy.library.ucsf.edu/tid/gvk21 e00 (Accessed 20 Jan 2004).

39 Lorillard. Log of All Sample 4's Distributed to Lorillard Employees [19831985]. 1983. Lorillard. Bates No. 87789439-87789449. http:// tobaccodocuments.org/lor/87789439-9449.html (Accessed 20 Dec 2004).

40 Lorillard. Sample 10 Log [1986-1988]. 1988. Lorillard. Bates No. 877891 12-877891 19. http://tobaccodocuments.org/lor/877891 12 9119.html (Accessed 20 Dec 2004).

41 Lorillard. Sample 10 Log [1989]. 1989. Lorillard. Bates No. 87810961 http://tobaccodocuments.org/lor/87810961.html (Accessed 20 Dec 2004).

42 Lorillard. Sample 10 Log [1989-1990]. 1990. Lorillard. Bates No. 87810960. http://tobaccodocuments.org/lor/87810960.html (Accessed 20 Dec 2004)

43 Lorillard. Sample 10 Log [1990]. 1990. Lorillard. Bates No. 87810959 http://tobaccodocuments.org/lor/87810959.html (Accessed 20 Dec 2004).

44 Lorillard. Log of Cigarettes/Favors/Etc. Dispensed [1991]. 1991. Lorillard. Bates No. 87810957. http://tobaccodocuments.org/lor/87810957.html (Accessed 20 Dec 2004).

45 Lorillard. Log of Cigarettes/Favors/Etc. Dispensed [1992]. 1992. Lorillard. Bates No. 87810955-87810956. hitp://tobaccodocuments.org/lor/ 87810955-0956. html (Accessed 20 Dec 2004).

46 Lorillard. Log of Cigarettes/Favors/Etc. Dispensed [1993]. 1993. Lorillard. Bates No. 87810954. http://tobaccodocuments.org/lor/87810954.html (Accessed 20 Dec 2004).

47 Philip Morris. 1998 Original Budget: Community Relations. 29 Oct 1997. Philip Morris. Bates No. 2070149003/9040. http:// legacy.library.ucsf.edu/tid/nfg47d00 (Accessed 20 Jan 2004).

48 Philip Morris. Philip Morris Employee Fund 1999 Grant Recipients. 1999. Philip Morris. Bates No. 2072141119/1121. http:// legacy.library.ucsf.edu/tid/kcf08d00 (Accessed 20 Jan 2004).

49 Luce T. Cardenas Fernandez and Associates. [Recipients for Thanksgiving donations by Marlboro music]. 28 Oct 1994. Philip Morris. Bates No. 2041949506. http://legacy.library.ucsf.edu/tid/xji87d00 (Accessed 20 Jan 2004).

50 Philip Morris. Fact Sheet. Jan 1998. Philip Morris. Bates No. 2072023971 http://legacy.library.ucsf.edu/tid/tvr47c00 (Accessed 20 Jan 2004).

51 Darden BC. The 2001 One Voice One Community Reception Miami Florida. 8 May 2001. Philip Morris. Bates No. 2085111 1425B/1426. http:// legacy.library.ucsf.edu/tid/mmal2c00 (Accessed 20 Jan 2004).

52 Nystrom S. Sun Sentinel. It's Murphys' Law: Feed the Homeless, 26 Mar 2000. Philip Morris. Bates No. 2080721571. http:// legacy.library.ucsf.edu/tid/loz91c00 (Accessed 20 Jan 2004).

53 Kivett M. Mental Health Association in Greensboro. [Letter thanking Lorillard for donation of cigarettes to residents]. 11 Dec 1990. Lorillard. Bates No. 87811135. http://legacy.library.ucsf.edu/tid/dpk2le00 (Accessed 7 Oct 2004).

54 Noonan RL. November 26-30, 1984 [Area Sales Directors' Monthly Reports]. 14 Dec 1984. RJ Reynolds. Bates No. 506074933/4937. http:// legacy.library.ucsf.edu/tid/xia05d00 (Accessed 20 Dec 2004).

55 RJ Reynolds. Institution Form. Gowanda Psychiatric Center [Promotions Allowed/Preferred]. 23 Feb 1995. RJ Reynolds. Bates No. 517189427/ 9427. http://legacy.library.ucsf.edu/tid/btl82d00 (Accessed 20 Dec 2004).

56 Friend KB, Pagano ME. Smoking initiation among nonsmokers during and following treatment for alcohol use disorders. Journal of Substance Abuse Treatment 2004:26:219-24.

57 Aloot CB, Vredevoe DL, Brecht ML. Evaluation of high-risk smoking practices used by the homeless. Cancer Nursing 1993;16:123-30.

58 Irvine EE, Bagnalasta M, Marcon C, et al. Nicotine self-administration and withdrawal: Modulation of anxiety in the social interaction test in rats. Psychopharmacology 2001;153:315-20.

59 Piccioto MR, Brunzell DH, Caldarone BJ. Effect of nicotine and nicotonic receptors on anxiety and depression. NeuroReport 2002;13:1097-106. 
60 Irving L, Seidner A, Burling TA, et al. Drug and alcohol abuse inpatients' attitudes about smoking cessation. Journal of Substance Abuse 1994;6:267-78.

61 Arnstein JH, Reid K, Bierer M et al. Smoking behavior and interest in quitting among homeless smokers. Addict Behav 2004;29:1 155-61.

62 Philip Morris. Public Place Exposure Cases (Non Employee Plaintiff). Jan 1997. Philip Morris. Bates No. 2072138269/8279. http:// legacy.library.ucsf.edu/tid/www32c00 (Accessed 20 Jan 2004).

63 Evins AE, Cather C, Rigotti N, et al. Two-year follow-up of a smoking cessation trial in patients with schizophrenia: increase rates of smoking cessation and reduction. J Clin Psychiatry 2004;65:307-11.

64 John U, Meyer C, Rumpf HJ, et al. Depressive disorders are related to nicotine dependence in the population but do not necessarily hamper smoking cessation. J Clin Psychiatry 2004;65:169-76.

65 Burling TA, Burling AS, Latini D. A Controlled smoking cessation trial for substance-dependent inpatients. J Consult Clin Psychol 2001;69:295-304

66 George TP, Vessicchio JC, Termine A, et al. A placebo controlled trial of bupropion for smoking cessation in schizophrenia. Biological Psychiatry 2002;52:53-61.

67 Dudas MM, George TP. Non-nicotine pharmacotherapies for nicotine dependence. Essential Psychopharmacology 2005;6:158-72.

68 Williams JM, Ziedonis DM, Foulds J. A case series of nicotine nasal spray in the treatment of tobacco dependence among patients with schizophrenia. Psychiatric Services 2004;55:1064-6.

69 Ziedonis D, Williams J, Smelson D. Serious mental illness and tobacco addiction: a model program to address this common but neglected issue. Am J Med Sci 2003:326:223-30.

70 Williams JM, Foulds J, Dwyer $M$, et al. The integration of tobacco dependence treatment and tobacco-free standards into residential addictions treatment in New Jersey. J Subst Abuse Treat 2005;28:331-40.

71 Evins AE, Cather C, Deckersbach T, et al. A double-blind placebo-controlled trial of bupropion sustained-release for smoking cessation in schizophrenia. J Clin Psychopharmacol 2005;25:218-25.

72 Philip Morris. Protocol for Inquiries About "Throwaways" Ad. Oct 2000. Philip Morris. Bates No. 2081615376. http://legacy.library.ucsf.edu/tid/ nwr65c00 (Accessed 20 Jan 2004).

73 Philip Morris. [Holy Apostles Soup Kitchen grant application]. 1997. Philip Morris. Bates No. 2081607639/7640. http://legacy.library.ucsf.edu/tid/ zar65c00 (Accessed 20 Jan 2004).

74 Philip Morris. Request for Funding. 14 Apr 1998. Philip Morris. Bates No. 2070380764/0771. http://legacy.library.ucsf.edu/tid/sdb47d00 (Accessed 20 Jan 2004).

75 Philip Morris Globe. Art Conservation Grant Gives New Life to Ancient Civilization. May 1998. Philip Morris. Bates No. 2076281631/1633. http://legacy.library.ucsf.edu/tid/vix45c00 (Accessed 20 Jan 2004).

76 Citrano S. Fanwood Scotch Plains Service League. [Letter requesting coupons for merchandise or goods]. Aug 1995. Philip Morris. Bates No. 2070079507/9509. http://legacy.library.ucsf.edu/tid/ntx08d00 (Accessed 20 Jan 2004).

77 Kligerman R. Brand X Menthol Distribution List. 1 May 1995. Philip Morris. Bates No. 2041445402/5426. http://legacy.library.ucsf.edu/tid/ ogh9la00 (Accessed 7 Oct 2004)

78 Santiago AM. Capital District Psychiatric Center. [Letter requesting cigarette donations for residents of psychiatric hospital]. 3 Jul 1995. RJ Reynolds. Bates No. 517224635/4636. http://legacy.library.ucsf.edu/tid/kfl80d00 (Accessed 7 Oct 2004)

79 Talan J. New York Newsday. Psychiatric Units Fume over Rule. 2 Apr 1994 Philip Morris. Bates No. 2071540446/0447. http:// legacy.library.ucsf.edu/tid/dic60c00 (Accessed 6 Jun 2005).

80 Ahlgren DG. Mental Health Association in Greensboro. [Letter requesting sample cigarette packs for residents]. 7 Dec 1989. Lorillard. Bates No. 87811165 . http://legacy.library.ucsf.edu/tid/gqk21e00 (Accessed 7 Oct 2004).

81 Moore DR. Integon Insurance, Wesley Hall of Alamance Boards of Directors. [Letter requesting donation of sample cigarettes for residents]. 5 Dec 1989. Lorillard. Bates No. 87811166 . http://legacy.library.ucsf.edu/tid/ hqk21e00 (Accessed 7 Oct 2004).

82 Haver DG. [Letter denying request for cigarettes for mental hospital residents]. 31 Jul 1995. RJ Reynolds. Bates No. 517224634/4634. http:// legacy.library.ucsf.edu/tid/jfl80d00 (Accessed 7 Oct 2004).

83 Haver DG. [Letter denying request for cigarettes for convalescent residents]. 22 Feb 1996. RJ Reynolds. Bates No. 517224641/4641. http:// legacy.library.ucsf.edu/tid/mfl80d00 (Accessed 7 Oct 2004).

84 Harvey MH. Residential Treatment Services of Alamance. [Letter requesting repeat donation of sample cigarettes for residents]. 24 Jan 1996. Lorillard. Bates No. 89286367. http://legacy.library.ucsf.edu/tid/gmt20e00 (Accessed 7 Oct 2004).

85 Dykes JH. Sunbridge Care. [Letter requesting sample cigarettes for nursing home residents]. 13 Oct 1999. RJ Reynolds. Bates No. 522749096/9097. http://legacy.library.ucsf.edu/tid/Hw80d00 (Accessed 7 Oct 2004)

86 Clark KK. Mental Health Association in Greensboro. [Letter requesting sample cigarette packs for residents]. 26 Aug 1987. Lorillard. Bates No. 87789291. http://legacy.library.ucsf.edu/tid/bfh21e00 (Accessed 7 Oct 2004).

87 Clark KK. Mental Health Association in Greensboro. [Letter requesting sample cigarette packs for residents]. $30 \mathrm{Sep}$ 1988. Lorillard. Bates No. 87789271. http://legacy.library.ucsf.edu/tid/leh21 e00 (Accessed 7 Oct 2004).

88 Dejournette M. Burlington/Alamance Jaycees. [Letter requesting sample cigarettes for residents]. 16 Nov 1988. Lorillard. Bates No. 87789150. http://legacy.library.ucsf.edu/tid/bbh21e00 (Accessed 7 Oct 2004).
89 Harvey MH. Wesley Hall of Alamance. [Letter requesting sample cigarettes for residents]. 20 Dec 1983. Lorillard. Bates No. 87789773. http:// legacy.library.ucsf.edu/tid/hpg21e00 (Accessed 7 Oct 2004).

90 Harvey MH. Residential Treatment Services of Alamance. [Letter requesting sample cigarettes for residents]. 3 Dec 1991. Lorillard. Bates No. 8781 1066. http://legacy.library.ucsf.edu/tid/qyk21 e00 (Accessed 7 Oct 2004).

91 Harvey MH. Residential Treatment Services of Alamance. [Letter requesting sample cigarettes for residents]. $25 \mathrm{Nov}$ 1992. Lorillard. Bates No. 87811014 . http://legacy.library.ucsf.edu/tid/qwk21e00 (Accessed 7 Oct 2004).

92 Harvey MH. Residential Treatment Services of Alamance. [Letter requesting repeat donation of sample cigarettes for residents]. 29 Nov 1995. Lorillard. Bates No. 89286373. http://legacy.library.ucsf.edu/tid/nmt20e00 (Accessed 7 Oct 2004).

93 Harvey MH, Webb K, Williams S. Alamance County Mental Health Association. [Letter thanking Lorillard for donation of cigarettes to residents]. 11 Jan 1990. Lorillard. Bates No. 87811161 . http:// legacy.library.ucsf.edu/tid/cqk21 e00 (Accessed 7 Oct 2004).

94 Kivett M, Plybon M, Plybon R. Mental Health Association in Greensboro. [Letter requesting cigarette donation for residents]. 9 Oct 1992. Lorillard. Bates No. 87811211 . http://legacy.library.ucsf.edu/tid/wrk21 e00 (Accessed 7 Oct 2004).

95 Kivett M, White J. Greensboro Mental Health Association. [Letter requesting cigarette donation for residents]. 30 Sep 1991. Lorillard. Bates No. 8781 1080. http://legacy.library.ucsf.edu/tid/cnk21 e00 (Accessed 7 Oct 2004).

96 Lucarelli F. Four Corners House. [Letter requesting cigarette donation for residents]. 25 Feb 1992. RJ Reynolds. Bates No. 508460550/0551. http:// legacy.library.ucsf.edu/tid/kwa38c00 (Accessed 20 Jan 2004).

97 Williams BI. Mental Health Association in Greensboro. [Letter requesting donation of cigarettes for residents]. 19 Nov 1985. Lorillard. Bates No. 87789719. http://legacy.library.ucsf.edu/tid/gog21 e00 (Accessed 7 Oct 2004).

98 Philip Morris. [Market Research Report: Benson and Hedges, Marlboro, Virginia Slims]. Sep 1991. Philip Morris. Bates No. 2047840304/0307. http://legacy.library.ucsf.edu/tid/ihp36e00 (Accessed 20 Jan 2004).

99 Nelson D. Philip Morris. 1988 Benson \& Hedges Command Performance Jazz Tour. May 1988. Philip Morris. Bates No. 2043418644/8647. http:// legacy.library.ucsf.edu/tid/uub93e00 (Accessed 20 Jan 2004).

100 Philip Morris. [Marketing status report, various brands]. May 1989. Philip Morris. Bates No. 2048515549/5579. http://legacy.library.ucsf.edu/tid/ kpm92e00 (Accessed 20 Jan 2004).

101 Kain R. International Merchandising, Philip Morris. International Merchandising Corporation and Philip Morris Incorporated Benson \& Hedges Command Performance Series on Ice Promoter Agreement. 1 Jun 1989. Philip Morris. Bates No. 2065015944/5964. http:// legacy.library.ucsf.edu/tid/apy04c00 (Accessed 20 Jan 2004)

102 Quindlen A. New York Times. Tobacco's Bad Money after Good. 17 Nov 1992. Tobacco Institute. Bates No. TIFL0009334. Florida AG. http:// legacy.library.ucsf.edu/tid/hqw12f00 (Accessed 20 Jan 2004).

103 New Times. Camel and Palapa Host Help the Tempe Homeless. 1999. Philip Morris. Bates No. 2084513356. http://legacy.library.ucsf.edu/tid/ hco7lc00 (Accessed 20 Jan 2004)

104 Nunn T. Tip Nunn's Events. [Memo identifying a new homeless organization in Philadelphia]. 31 Aug 1992. Philip Morris. Bates No. 2071200169. http://legacy.library.ucsf.edu/tid/ohq37d00 (Accessed 20 Jan 2004)

105 Nunn T. Tip Nunn's Events. [Memo identifying homeless organizations in club markets]. 4 Sep 1992. Philip Morris. Bates No. 2071200170/0172. http://legacy.library.ucsf.edu/tid/phq37d00 (Accessed 20 Jan 2004).

106 O'Neill S. Benson and Hedges Blues. 8 Jun 1990. Village View. Bates No 2025426179. http://tobaccodocuments.org/pm/2025426169-6185.htm (Accessed 28 Oct 2004)

107 Doyle M, Heim C, Hoekstra D, et al. Chicago Sun Times, Chicago Tribune, Post Tribune. Benson \& Hedges Blues Public Relations. 1990. Philip Morris. Bates No. 2040567520/7531. http://legacy.library.ucsf.edu/tid/ ydq02a00 (Accessed 28 Oct 2004)

108 MRE Info. Meal, Combat, Individual. 11 Oct 2004. http:// www.mreinfo.com/mcis.html (Accessed 28 Oct 2004).

109 Philip Morris. Philip Morris USA Corporate Affairs Department Meeting. 11 Jul 2001. Philip Morris. Bates No. 2085581520/1591. http:// legacy.library.ucsf.edu/tid/gly21c00 (Accessed 13 Jul 2004).

110 National Coalition for the Homeless. Homeless Veterans (NCH Fact Sheet \#9). Jan 2004. http://www.nationalhomeless.org/veterans.html (Accessed 16 Dec 2004)

111 Department of Veterans Affairs. Homelessness Among Veterans. 3 May 2004. http://wwwl.va.gov/homeless/page.cfm?pg = 1 (Accessed 3 Apr 2004)

112 Associations Unlimited. http://galenet.galegroup.com/servlet/ AU?locID = uc856info (Accessed 16 Dec 2004)

113 Philip Morris. Nonscience Witness List OSHA Hearing. 29 Sep 1994. Philip Morris. Bates No. 2064227496/7539. http://legacy.library.ucsf.edu/tid/ rtg32a00 (Accessed 20 Jan 2004).

114 Philip Morris. Bar Settings Strategy Team Meeting. 16 Jun 1997. Philip Morris. Bates No. 2065520143/0155. http://legacy.library.ucsf.edu/tid/ ioe73c00 (Accessed 20 Jan 2004).

115 Philip Morris. State Smoking Laws for Bars and Taverns. 31 Dec 1997. Philip Morris. Bates No. 2077904011/4023. http://legacy.library.ucsf.edu/tid/ ojx37c00 (Accessed 20 Jan 2004).

116 Fitzpatrick R. National Coalition For Homeless Veterans. Exhibit 95 Testimony by Richard Fitzpatrick, Executive Director National Coalition for Homeless Veterans 1 November 1994 Concerning OSHA's Proposed Indoor 
Air Quality Standards (Docket No. H 122). 1 Nov 1994. RJ Reynolds. Bates No. 512682289/2292. http://legacy.library.ucsf.edu/tid/smf50d00 (Accessed 20 Jan 2004).

117 Duchin R. MBD Program Suggestions for 1995. 6 Apr 1995. RJ Reynolds. Bates No. 51 1997965/7969. http://legacy.library.ucsf.edu/tid/ mat40d00 (Accessed 20 Jan 2004).

118 Tomb H. [Draft advertisement noting organizations supported by Philip Morris in Colorado]. 11 Nov 1996. Philip Morris. Bates No. 2065393226/ 3227. http://legacy.library.ucsf.edu/tid/khx43a00 (Accessed $28 \mathrm{Jul}$ 2004).

119 Smith EA, Malone RE. Altria means tobacco: Philip Morris's identity crisis. Am J Public Health 2003;93:553-6.

120 Philip Morris. [Colorado organizations supported by Philip Morris]. Feb 1999. Philip Morris. Bates No. 2072308855. http:// legacy.library.ucsf.edu/tid/kgh06c00 (Accessed 20 Jan 2004)

121 Quixote Group, Craig H. Red, White and Blue Salute. 30 Oct 2000. RJ Reynolds. Bates No. 525220640/0760. http://legacy.library.ucsf.edu/tid/ iag70d00 (Accessed 13 Jul 2004).

122 Psychiatric News. Mental Illness Advocacy Group Battling Hospital Smoking Ban in New York. 16 Sep 1994. Philip Morris. Bates No. 2071540448. http://legacy.library.ucsf.edu/tid/cic60c00 (Accessed 22 Jul 2004).

123 Philip Morris. FYI Edition. 26 Oct 1994. Philip Morris. Bates No. 20411 28423/8548. http://legacy.library.ucsf.edu/tid/vgd05e00 (Accessed 16 Sep 2003).

124 Philip Morris. Workplace Exposure Cases. Aug 1998. Philip Morris. Bates No. 2072138028/8048. http://legacy.library.ucsf.edu/tid/klw32c00 (Accessed 20 Jan 2004)

125 Sachs-Ericsson N, Wise E, Debrody CP, et al. Health problems and service utilization in the homeless. Journal of Health Care for the Poor and Underserved 1999; 10:443-52.
126 Wrenn K. Immersion foot: a problem of the homeless in the 1990s. Arch Intern Med 1991;151:785-8

127 Solsona J, Cayla JA, Nadal J, et al. Screening for tuberculosis upon admission to shelters and free-meal services. Eur J Epidemiol 2001; 17:123-8.

128 Butler J, Okuyemi KS, Jean S, et al. Smoking characteristics of a homeless population. Substance Abuse 2002;23:223-31.

129 Philip Morris. [Maintaining a successful relationship with Kentucky mass media]. Mar 1995. Philip Morris. Bates No. 2044270215/0219. http:// legacy. library.ucsf.edu/tid/spu53a00 (Accessed 20 Jan 2004).

130 Matthews EW. [Letter denying request for cigarette or coupon donation]. 31 Aug 1999. RJ Reynolds. Bates No. 522496781/6781. http:// legacy.library.ucsf.edu/tid/vvo70d00 (Accessed 7 Oct 2004).

131 RJ Reynolds. R.J. Reynolds Tobacco Company's Position on Youth NonSmoking. http://rirt.com/TI/Tlyouthsmoking_cover.asp (Accessed 13 Jan 2005).

132 Rosenheck RA, Dausey DJ, Frisman L, et al. Outcomes after initial receipt of social security benefits among homeless veterans with mental illness. Psychiatric Services 2000;51:1549-54.

133 Steinberg ML, Williams JM, Ziedonis DM. Financial implications of cigarette smoking among individuals with schizophrenia. Tobacco Control 2004; 13:206

134 Balbach ED, Gasior RJ, Barbeau EM. R.J. Reynolds targeting of African Americans: 1988-2000, Am J Public Health 2003:93:822-7.

135 Robinson RG, Sutton CD. The coalition against Uptown cigarettes. In: Jernigan D, Wright PA, eds. Making news, changing policy: case studies of media advocacy on alcohol and tobacco issues. San Francisco: University Research Corporation, The Marin Institute for the Prevention of Alcohol and Other Drug Problems, 1994.

\section{The Lighter Side}

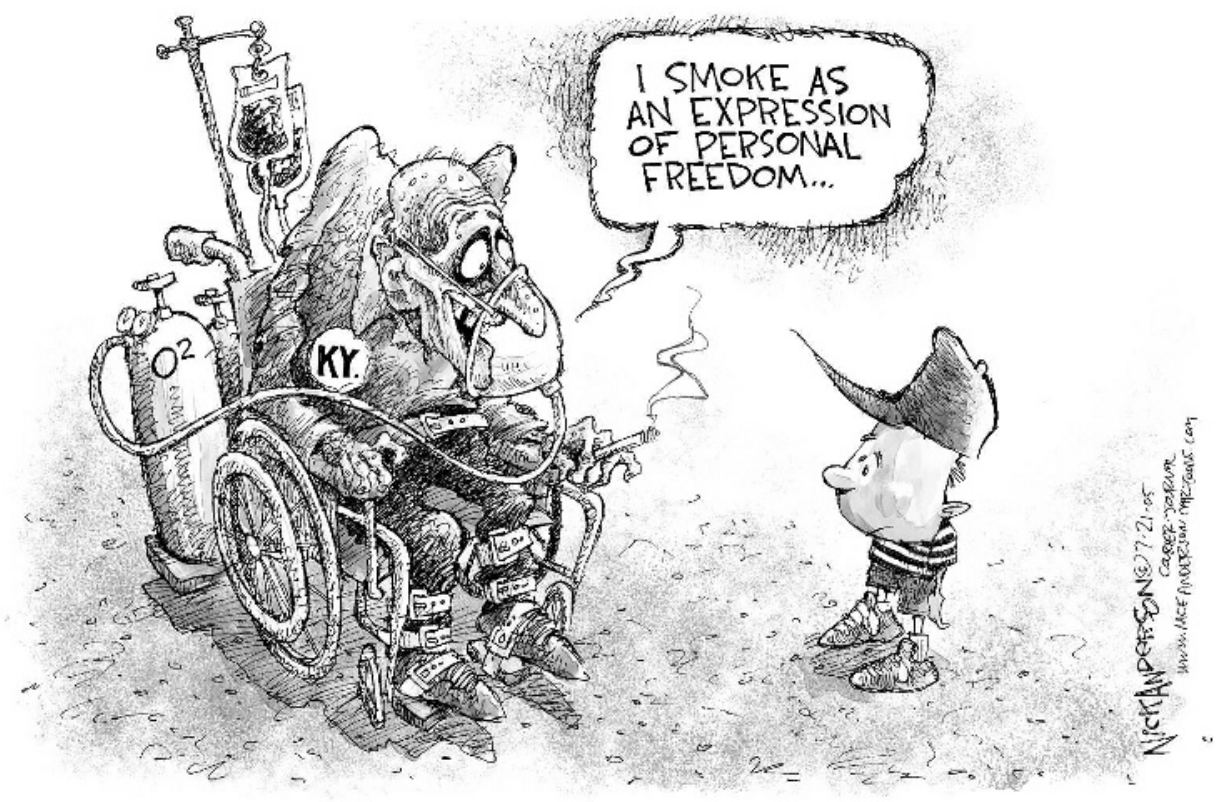

(c) 2005, Nick Andersen. Distributed by The Washington Post Writers Group. Reprinted with permission. 